\title{
NCPAP FOR THE TREATMENT OF OBSTRUCTIVE SLEEP APNEA
}

\author{
4DEMIR BAPTISTA SILVA* - HELIO LEMMI*;
}

SUMMARY - Nasal continuous positive airway pressure (NCPAP) represents a real advance in the management of obstructive sleep apnea (OSA). Our data show that except for awakenings, all sleep and respiratory parameters were significantly improved $(p<0.05)$ in favor of the group treated with NCPAP. A main problem with NCPAP is the acceptance by the patient; it also may disturb the sleep, at least, on short term basis and, in a small number of patients, it does not correct the anneas. In our patients series, males responded better to NCPAP than females.

\section{Tratamento da apnéia obstrutiva do sono pelo NCPAP}

RESUMO - O tratamento da apnéia obstrutiva do sono pelo NCPAP (pressāo positiva continua nasal) vem se tornando rotina, pois este tratamento substitui fi traqueostomia em muitos casos. O NCPAP, às vezes, nāo '́ tolerado pelo paciente, constituindo este fato um obice an seu uso mais abrangente. De maneira geral, todos os índices da pulissonografia mostraram modificaçōes estatisticamente significantes, exceto para o número de despertares comoletọs. Este fato indica que os parâmetros que avaliam a qualidade do sono nāo seguem aqueles quc avaliam a função respiratória em alguns pacientes. Em pequeno número de pacientes, essta modalidade de tratamento não funciona. Por outro lado, nossos dados revelaram que os pacientes do sexo masculino respondem melhor ao NCPAP que os do sexo teminino e que o quadro da apnéia é mais grave no grupo feminino, aparecenđo mais brecocemente. Estes dados $\$ \bar{n} 0$ nrēiminares e foram obtidos para uma amostra pequena, nectssitando de confirmaçăo em uma série maior de nacientes.

Three new treatments for OSAS have appeared lately in the medical literature 2,11,13. Uvulopalatopharingoplasty (UPPP), gastroplasty and NCPAP were introduced to substitute tracheostomy, previously, the only effective treatment available 1,3,5,6. Gastroplasty and UPPP have specific indications respectively morbid obesity and redundánt oropharingeal tissue. Because NCPAP has a more wide range of indications, in our Center, patients with OSA are routinely tried on this form of treatment. Some patients are treated with NCPAP on a temporary basis, until a more definitive treatment such as UPPP or weight reduction is accomplished. Long term follow up of patients responsive to NCPAP have been reported $8-10,12$. Our analysis in this study is in reference to the effectiveness of NCPAP on a short term basis.

\section{METHODS}

We studied 22 patients, evaluated at Baptist Memorial Hospital Sleop Disorders Center in Memphis, who were tested with NCPAP the night following the diagnostic polysomnography (PSG) documenting OSA. The PSG consisted of the electroencephalogram (EEG) recorded from C3-A2 and C4-A1, chin-electromyogram (EMG), leg-EMG, nasal and buccal

From Baptist Memorial Hospital Sleep Disorders Center (Memphis): $;$ Fellow from Escola Paulista de Medicina (Sảo Paulo) with grant from CNPq: ** Director of Sleep Disorders Center.

Sleep Disorders Center, Baptist Memorial Hospital - 899 Madison Avenue - Memphis, TN $38146-U S A$. 
thermocouples, thoraxic and abdominal strain-gauges and blood 02 saturation monitoring. The PSG were recorded in noise attenuated room with constant temperature around 230C. The patients were monitorized by low light video-camera with infra-red illumination as well microphones. The analysis of the recordings were done according to Rechtschaffen and Kales criteria $(\gamma)$. The data were submitted to statistical analysis by wilcoxon rank test, comparing before and after treatment indexes. For the purpose of this research, we considered the apnea index (A1), the number of apneas per hour of sleep, less than 5 for males and up to 1 for females as being normal. The target point of maximum improvement for normal sleep were the parameters set forth by Williams et al. (Ii).

\section{RESULTS}

The clinical and polysomnographic characteristics of our sample are presented in tables 1 to 4

\begin{tabular}{lrrrr}
\hline Sex & n & Age (yrs) range & WT (lbs) range & HT (ft) range \\
\hline Male & 16 & $49.2(28-75)$ & $243.7(180-345)$ & $6^{\prime} 10^{\prime \prime}\left(5^{\prime} 7^{\prime \prime}-6^{\prime} 4^{\prime \prime}\right)$ \\
Female & 6 & $37.0(31-61)$ & $267.8(179-338)$ & $5^{\prime} 4^{\prime \prime}\left(5^{\prime} 1^{\prime \prime}-5^{\prime} 6^{\prime \prime}\right)$ \\
\hline
\end{tabular}

Table 1 - Clinical characteristics of the patients with OSA. WT, weight; HT, height; $n$, number of patients.

\begin{tabular}{|c|c|c|c|c|c|}
\hline Parameter & Before & $\mathrm{sd}$ & After & sd & $P \leqslant 0.05$ \\
\hline Apnea Index & 45.0 & 28.0 & 8.0 & 10.0 & $s$ \\
\hline 02 saturation $\%$ & 64.6 & 12.9 & 84.9 & 8.5 & $s$ \\
\hline " of arousuls & 287.6 & 186.4 & 56.9 & 44.0 & $\therefore$ \\
\hline * of awakenings & 4.2 & 2.6 & 5.0 & 5.0 & $\mathrm{~ns}$ \\
\hline Slow wave sleep $\%$ & 6.7 & 2.6 & 21.7 & 5.0 & s \\
\hline
\end{tabular}

Table 2 - Slecp parameters before and after NCPAP. sd, standard deviation; s, significant; ns, non significant.

\begin{tabular}{ccccc} 
Sex & Partial & Ineffective & Not tolerated \\
Miale & 12 & 2 & 1 & 1 \\
Feniale & 1 & 3 & 2 & 0 \\
\hline
\end{tabular}

Table : - NCPAP effectiveness according to sex.

\begin{tabular}{llrcc}
\hline & Parameter & Improved & Worsened & Not changed \\
\hline Arousals & 21 & 1 & 0 \\
& Awakenings & 7 & 10 & 3 \\
Slow wave sleep & 19 & 3 & 0 \\
\hline
\end{tabular}




\section{COMMENTS}

NCPAP worked very well for all sleep parameters, except for the number of awakenings. It is interesting to note that males with apneas predominate over females, but apnea indexes were higher in females. The mean age was lower for females than for males. Females were heavier than males, even without weight correction for sex. NCPAP was more effective for males than for females, when measured by apnea indexes after treatment. While not all patients improve on NCPAP 14, it has become the most important short term treatment for obstructive apneas in addition to being effective as long term therapy for some patients $4,9,10$. In this present series, 3 patients didn't improve on NCPAP and 1 did not tolerate it. Partial improvements were ubserved in 5 cases. The patients who did not respond to NCPAP as measured by apnea index had continued to have abnormal steep parameters. On the other hand, patients who improved their apnea indexes on NCPAP either did not improved the sleep parameters or in some cases even became worse (Table 4), a fact that is of some concern in long term NCPAP therapy. This problem may impact long term compliance rate.

\section{REFERENCES}

1. Conk WR, Osguthorpe JD $\rightarrow$ Obstructive sleen apnea: diagnosis and treatment. J South Carol Med Assoc 81:647, 1985.

2. Fuita S, Conway W, Zorick F, Roth T - Surgical correction of anatomic abnormalities in obstructive sleep apnea syndrome: uvulopalatopharyngoplasty. Otolaryngol Head Neck Surg $89: 923,1981$.

3. Guilleminault C, Dement WC - The sleep apnea syndrome. Am Rev Med 27:465, 1976.

4. Issa FG, Sullivan $\mathrm{CE}$ - The immediate effects of nasal confinuous positive airway pressure treatment on sleep pattern in patients with obstructive sleep apnea syndrome. EEG Clin Neurophysiol 6:3:10, 1986.

5. Krieger J, Kurtz D - Treatment ot obstructive sleep apnea. Lancet 2:1177, 1984.

6. Krieger $J$ - Sleep apnea: from the needles of Dionysious to continuous positive airway pressure. Arch Intern Med 143:2301, 1983.

7. Remmers JE, Sterling JA, Thorarinsson B, Kuna ST - Nasal airway positive pressure in patients with occlusive sleep apnea. Am Rev Resp Dis 130:1152, 1984.

8. Sanders MD, Gruendl CA, Rogers RM - Patients compliance with nasai NCPAP therapy for sleep apnea. Chest 90:330, 1986.

9. Schmidt-Nowara WW - Continuous positive airway pressure for loug-term treatment of sleep apnea. Am J D:s Child 138:82, 1984.

10. Sleeper GP, Strohl KP, Armeni MA - Nasal continuous positive airway pressure for at-home treatment of obstructive sleep apnea: a case report. Resp Care 30:90, 1985.

11. Sugerman HJ, Fairmam RP, Lindeman AK, Mathers JAL., Greenfield LJ — Gastroplasty for respiratory insufficiency of obesity. Ann Surg 198:677, 1981.

12. Sullivan CE, Berthon-Jones M, Issa FG - Nocturnal nasal airway oressure for sleep annea. N Engl J Med $309: 112,1983$.

13. Sullivan CE, Issa FG, Berthon-Jones M, Eves L - Reversal of obstructive sleep apnea by continuous positive airway pressure applied through the nose. Lancet 1:862, 1981.

14. Wazner DR, Pollack CP, Weitzman ED - Nocturnal nasal airway pressure for sleep apnea. N Engl J Med 308:461, 1983.

15. Williams RL, Karacan I, Hursch CJ - Electroencephalography (EEG) of Human Sleep: Clinical Applications. John Wiley \& Sons, New York, 1974. 